\title{
Agnes Maule Machar on the Higher Education of Women
}

\author{
Dianne M. Hallman
}

Agnes Machar (1837-1927) was an ardent advocate of higher education for women and for the opening of new fields of work to them in the last quarter of the nineteenth century in Canada. Her position on this subject earned her a reputation in the late twentieth century as a moderate feminist. ${ }^{1}$ Access to higher education and the professions ultimately affected few women in nineteenth-century Canada. Yet the question of access, and the degree to which it was achieved had symbolic and practical consequences for women generally, and had important meanings in and for the "woman movement." The nineteenth-century struggle for women's rights was based in two distinct claims: the first urged women's emancipation based on their equal claims to humanity, the other argued for an extension of women's sphere based on their peculiar role as "guardians of the home."” These different views co-existed more or less comfortably in Machar's thought.

Machar was born in Kingston, Upper Canada, and made her home there all her ninety years. Her father was the long-time pastor of St. Andrew's Presbyterian Church and served two terms as Principal of Queen's College (1846-53). Her mother was, according to one observer, all that a "minister's wife" was expected to be, an exemplar of Christian piety and good works. ${ }^{3}$ An older brother died in infancy. Her younger brother, John, had the benefit

1. Ramsay Cook, The Regenerators: Social Criticism in Late Victorian English Canada (Toronto: University of Toronto Press, 1985), 119; Ruth Compton Brouwer, "The 'Between-Age' Christianity of Agnes Machar,” Canadian Historical Review 65, 3 (1984): 347-70; Ruth Compton Brouwer, "Moral Nationalism in Victorian Canada: The Case of Agnes Machar,” Journal of Canadian Studies (Spring 1985): 90-108; and Nancy Miller Chenier, "Agnes Maule Machar: Her Life, Her Social Concerns, and a Preliminary Bibliography of Her Writing” (M.A. thesis, Carleton University, 1977), 27-39.

2. Alison Prentice, Paula Bourne, Gail Cuthbert Brandt, Beth Light, Wendy Mitchinson, and Naomi Black, Canadian Women: A History (Toronto: Harcourt, Brace Jovanovich, 1988), 169.

3. United Church Archives, Victoria University, Biographical file, "Rev. Dr. John Machar," clipping, D.J. Macdonnell, "In Memoriam: Mrs. Machar,” The Canada Presbyterian 11/46 (November 1883): 732.

(C) Historical Studies in Education/Revue d'histoire de l'éducation 13, 2 (2001): 165-82 
of university studies denied women at the time and became a prominent barrister in Kingston. ${ }^{4}$

Apart from a year at a boarding school in Montreal under the direction of Miss Hannah Lyman (later Lady Principal of Vassar College), Machar's education was supervised at home by her father. Girls of the upper-middle and professional classes were usually educated this way. Rev. Machar's fine library helped many who would later become prominent citizens, among them John A. MacDonald and Oliver Mowat.

Agnes enjoyed a broad and rigorous education, further enriched by stimulating company at the manse. As an adult, she followed her mother's example of Christian service, supporting several reform and cultural organizations, including the National Council of Women of Canada and the Kingston Local Council. She was an active member of the national and local councils from their establishment in 1893 and 1894 respectively. ${ }^{5}$ Although not the most radical of women's organizations, the ncwc promoted education for women and served as a forum for women's education. ${ }^{6}$

Machar's thought on social and political issues was shaped by the liberal idealism and social Christianity of the Queen's intellectual community. ${ }^{7}$ In her own long career as writer and social reformer, she entered public debates close to the heart of the social gospel: the right relation of science and religion, the capital/labour question, temperance, and improvidence. She argued subtle points in theology, religious doctrine, morality, and empiricism with Canada's most influential thinkers, mostly in the Canadian Monthly and National Review (founded in 1871), its successor Rose Belford's Canadian Monthly and National Review, and later, The Week. These were the leading intellectual journals of English Canada where highly educated men promulgated their views on events and issues of the day. Machar was a regular contributor,

4. Dianne M. Hallman, "Cultivating a Love of Canada through History: Agnes Maule Machar, 1837-1927," in Creating Historical Memory: English-Canadian Women and the Work of History, ed. Beverley Boutilier and Alison Prentice (Vancouver: University of British Columbia Press, 1997), 25-50.

5. Ibid., 30-1.

6. N.E.S. Griffiths, The Splendid Vision: Centennial History of the National Council of Women of Canada, 1893-1993 (Ottawa: Carleton University Press, 1993).

7. A.B. McKillop, A Disciplined Intelligence: Critical Inquiry and Canadian Thought in the Victorian Era (Montreal: McGill-Queen’s University Press, 1979), 217-24. 
frequently under her pen-name Fidelis, a name that symbolized her unwavering Christian faith and hid her female identity. ${ }^{8}$

During the 1870s Machar established herself as a writer with the publication of four novels, two dozen essays, several poems, and a memorial to her father. ${ }^{9}$ By the end of her career, the corpus of her work was considerable and forgettable. Late twentiethcentury commentators typically describe her as a quaint figure representative of a distant past. ${ }^{10}$ Yet she was remarkable. Whether by choice or chance she never married, and thus lived outside the prescribed role for women. Helped no doubt by her race and class privilege and by her celibate status, she became one of few women of the day to succeed as a writer. Moreover, the fusion of "reformist, feminist, religious, and patriotic concerns" 11 that characterized her work reveals much about Victorian Canadian thought and the status of women.

In a country whose colonists had been preoccupied with matters of survival, "formal schooling, even where it was desired, was difficult to establish and sustain." "Few obtained an education beyond the rudiments. For more advanced studies the tradition of separate education prevailed, with boys studying Latin, Greek, and other academic subjects at grammar schools and seminaries, and girls studying academic, religious, and ornamental subjects at academies developed under denominational or private auspices. By the 1870s, basic education was provided in common or elementary schools and the development of secondary education or high schools was underway in most provinces. But in Ontario, legal provision in 1871 for Collegiate Institutes to be classical schools (intended for boys) discouraged the enrolment of girls in the classical, university preparatory course. ${ }^{13}$ Over the next few

8. Cook, The Regenerators, 8. Some other regular contributors were Goldwin Smith, John Watson, George Monro Grant, William Dawson, and W.D. LeSueur.

9. Hallman, "Cultivating a Love of Canada," 32.

10. See, for example, Carole Gerson, “Three Writers of Victorian Canada,” in Canadian Writers and Their Works, ed. Robert Lecker, Jack David, and Ellen Quigsley (Downsview: ECW Press, 1983).

11. Alvin Finkel, Margaret Conrad, with Veronica Strong-Boag, History of the Canadian Peoples, 1867 to the Present (Toronto: Copp Clark Pitman, 1993), Vol. II: 152.

12. Paul Axelrod, The Promise of Schooling: Education in Canada, 1800-1914 (Toronto: University of Toronto Press, 1997), 12.

13. Marion V. Royce, "Arguments Over the Education of Girls-Their Admission to Grammar Schools in this Province,” Ontario History 47 (Mar. 1975): 1-13, esp. 13; see also R.D. Gidney and W.P.J. Millar, Inventing Secondary Education: The Rise of the High School in Nineteenth-Century Ontario (Montreal and Kingston: McGill-Queen's 
decades, provincial legislation providing for free and then compulsory schooling was enacted across the country. Coeducation was widely practised in early grades and with the passing of the years, and certainly by 1914, at the secondary level in most of English-speaking Canada. ${ }^{14}$

Canadian universities in the 1870s were predominantly small church-run colleges where privileged young men studied the classical curriculum on their way to becoming "professional gentlemen." ${ }^{15}$ As the scientific paradigm superceded theology, scientific and professional studies expanded and the state increasingly assumed control of the institutions. Women, with the support of influential men like Machar's friend George Monro Grant, gradually pried their way into universities and professional training. Mount Allison became the first university in the British empire to award a degree to a woman when Grace Annie Lockhart received a B.Sc. in 1875. During the 1880s, other universities in English-speaking Canada opened at least some of their programmes to women. Discourses of anxiety and opposition accompanied women's entry into university education. ${ }^{16}$

Machar was one of the few women in Canada to take up the subject. Her six or seven essays in The Canadian Monthly and The Week over a fifteen-year period brought together and put before a Canadian audience the views of her day on higher education and appropriate professions for women. She drew primarily from British and American sources with little specific reference to how higher education for women was evolving in these countries. Machar's discussion touched on women's reproductive health, natural and cultural differences between the sexes, a critique of male and female models of higher education, the benefits and drawbacks of co-education, and the purposes of a liberal as opposed to a specialized education for women.

Machar's views are an interesting alloy of ideas about the equality and specificity of the sexes. Like other speakers on the subject, she formulated and buttressed her arguments from an eclectic range of romantic poetry, history, classical literature, and the Bible, all seasoned with a dash of empiricism.

University Press, 1990), 209.

14. J. Donald Wilson, Robert M. Stamp, Louis-Philippe Audet, eds., Canadian Education: A History (Scarborough: Prentice-Hall,1970), 324.

15. R.D. Gidney and W.P.J. Millar, Professional Gentlemen: The Professions in Nineteenth-Century Ontario (Toronto: University of Toronto Press, 1994).

16. See Prentice et al., Canadian Women, 155-62. 
The debate about women's higher education should be set against the contemporary claims of doctors to exercise authority over women's lives. Victorian Canadians increasingly left it up to doctors to explain how women differed from men. Doctors, for their part, defined these differences in terms of the "reproductive/sexual system" and located in that system the origin of most female health problems and disease. Although Canadian women may have in fact been stronger and healthier than men, doctors developed and elaborated an image of women as the constitutionally frailer sex. As doctors became the "priests of the body," their authority extended into all aspects of women's lives. ${ }^{17}$ With the interests of future generations allegedly at heart, medical men believed they should regulate what women ate, wore, read, whether they sat or stood and upon what. Ideas in the 1870s about the proper education for women came largely from the views of doctors in the United States and Britain. ${ }^{18}$

Machar's first article on women's higher education joined a lively discussion of the 1873 publication in the United States of Dr. Edward Clarke's Sex in Education and of Dr. Henry Maudsley's "Sex in Mind and in Education," a slightly later but similar piece in an English periodical. ${ }^{19}$ Polemics like these raised the alarm that modelling women's education on men's was dangerous to their health, particularly for their reproductive capacity. Clarke and Maudsley drew on the Spencerian notion of a closed energy system and argued that women endangered their capacity to bear children by submitting themselves to the unremitting brain work required in studies designed for boys and young men. Such sustained effort without rest during their periodical function was held to be largely

17. Wendy Mitchinson, The Nature of Their Bodies: Women and Their Doctors in Victorian Canada (Toronto: University of Toronto Press, 1991), Chapter 2, esp. 51 and 63-76. "Priests of the body" is an expression borrowed from Michel Foucault, The Birth of the Clinic: An Archaeology of Medical Perception (New York: Pantheon Books, 1973), 32.

18. For how the debate was picked up in Canadian medical journals, see Mitchinson, The Nature of Their Bodies, 83-87, and Constance Backhouse, Petticoats and Prejudice: Women and Law in Nineteenth-Century Canada (Toronto: Osgoode Society/Women's Press, 1991), 297-9. The views of medical men and "lady doctors" on female education were also circulated in education journals such as The Canada Educational Monthly. See, for example, N. Allen, "The Education of Girls, as Connected with Their Growth and Physical Development,” The Canada Educational Monthly 1 (Sept. 1879): 412-20.

19. Edward H. Clarke, Sex in Education; or, A Fair Chance for the Girls (Boston: Osgood, 1873); Henry Maudsley, "Sex in Mind and in Education," Fortnightly Review New Series, 15 (1874): 467-83. 
responsible for the increase in ill health and sterility among women of the upper and middle classes. The wide dissemination of Clarke's and Maudsley's views on the negative effects on women of an education identical to that of their brothers fuelled a fierce and lengthy debate on both sides of the Atlantic. Yet the debate did not stem the tide of women seeking higher education nor slow down the practice of co-education.

Late twentieth-century interpretations of this debate have emphasized how Social Darwinists gave scientific credence and authority to the view that biology is destiny.$^{20}$ For women, this meant lives dominated by reproduction; that is, "the empirically revealed, ironclad laws of biology" were to be the final word on what women could do. ${ }^{21}$ Clarke and Maudsley shifted the arguments against women's higher education from women's presumed intellectual inferiority to their presumed physiological incapacity. ${ }^{22}$ Nevertheless, Clarke's book was sharply criticized on scientific grounds even in its own day. ${ }^{23}$ The work was as much a mixture of anecdotal testimony, moral suasion, romantic sensibility, and vague Christianity as anything written in response to it. The same may be said for the Maudsley article. The horticultural metaphors and literary allusions may have carried as much weight with readers as the appeal to the laws of physiology.

Through their emphasis on the negative effects on women of education identical in content, method, and rate of acquisition to that of men, Clarke, Maudsley, and others like them invited critics to speculate about the harm done to young men by that same model, and to question its very usefulness. To this point Machar returned time and again in discussing the cramming system. Overloading the curriculum or requiring children to do several hours of close mental work after school was just as likely to

20. For a definition of Social Darwinism and its impact on school policy in Britain, see Carol Dyhouse, “Social Darwinistic Ideas and the Development of Women's Education in England 1880-1920,” History of Education 5 (1976): 41-58.

21. Sue Zschoche, "Dr. Clarke Revisited: Science, True Womanhood, and Female Collegiate Education,” History of Education Quarterly 29, 4 (Winter 1989): 545-69; quotation, 549.

22. See Anne Brackett, ed., The Education of American Girls Considered in a Series of Essays (New York: Putnam, 1884), 93.

23. See the contribution by Thomas Wentworth Higginson to Julia Ward Howe, ed., Sex and Education: A Reply to Dr. E.H. Clarke’s “Sex in Education” (New York: Arno Press, 1972; first published 1874), 3-51. On p. 6 of her introduction to this collection, Howe referred to Clarke's book as having "found a chance at the girls, rather than a chance for them." 
damage boys as girls. Furthermore, Machar pointed out that instances of injury among boys were hardly likely to be taken as evidence that their higher education was a mistake. She allowed that boys were more likely to save themselves from overwork by refusing to do it. ${ }^{24}$

Machar's 1875 article under her pen-name Fidelis summarized the views of Clarke and Maudsley, and showed how their charges had been answered by educators in female colleges and coeducational institutions in America. ${ }^{25}$ Part of this debate was whether there were mental differences between the sexes that correlated with physical differences. Maudsley and Clarke took the position there were. ${ }^{26}$ Although Maudsley was not precise as to what those mental differences were, he understood them to be those that made woman the perfect complement of man, and enabled women to care for children, an activity he was sure would soon be given up "in despair or in disgust" if left to men, and the continued propagation of the earth deemed "not worth while."27

Machar conceded that there were mental differences between women and men, and she was specific about what they entailed. She allowed that women were naturally governed by instinct, imagination, impulse, and emotion, rather than logic or purpose. For this reason, girls should be given a systematic education in the same subjects as boys. Just as boys' and girls' physical natures were nourished by the same food, so their mental natures would be nourished by the same studies: "Though mental characteristics may differ, the mental processes as well as the nutritive processes, are the same in both sexes, and what invigorates these in one sex will be found to have the same effect in the other also." She further argued the aim of education should be to strengthen the weak or deficient faculties and prevent the strong "from attaining an undue

24. Fidelis, “New Ideal of Womanhood," Rose-Belford's Canadian Monthly 2 (June 1879): 659-76.

25. Fidelis, "Higher Education for Women,” The Canadian Monthly and National Review 7 (Feb. 1875): 144-57. Among the responses to Clarke and Maudsley reviewed by Machar were Elizabeth Garrett Anderson, "Sex in Mind and Education: A Reply,” Fortnightly Review 15(1874): 582-94; Brackett, ed., The Education of American Girls; E.B. Duffey, No Sex in Education; Or, An Equal Chance for Both Girls and Boys (Philadelphia: J.M. Stoddard, 1874); Howe, ed., Sex and Education: A Reply.

26. Maudsley, "Sex in Mind," 468;Clarke, Sex in Education, 16, 32-5, 89.

27. Maudsley, "Sex in Mind," 472. 
preponderance. ${ }^{28}$ In a later article, Machar exposed a contradiction in traditionalist arguments:

It is curious, how pertinaciously the idea has been clung to by the opponents of reform, that it is the imagination and the affections which woman should chiefly cultivate; in face of their own argument that her strong prejudices, which are of course the outcome of affection and imagination unregulated by sound judgement, must always disqualify her from forming an intelligent opinion on great social or political questions. Can the reason be, that they unconsciously desire to perpetuate the disqualification ${ }^{29}$

Women's weaker reflective and reasoning power and poorer judgement needed the "severer studies" that "brace the mental constitution," studies such as mathematics, languages (thoroughly learned), mental philosophy, and logic.

Had boys been, for generations past, educated on the same miserably superficial system which has been the rule with girls, filling their minds with an undigested chaos of heterogeneous facts, and expending their energies on a number of so-called 'accomplishments', all imperfectly acquired, it is probable that their minds would have exhibited much of the superficiality and inaccuracy which had been so long held to demonstrate the great mental inferiority of women. ${ }^{30}$

Here Machar was taking a controversial position similar to one recently put forward by J.S. Mill, among others, which argued that what was widely assumed to be natural differences between the sexes could instead be the result of culture (or, in the nineteenthcentury sense of the word, want of culture). ${ }^{31}$ She was also

28. Fidelis, "Higher Education for Women,” 149. See also Agnes Maule Machar, "The Higher Education of Women,” The Week 7 (27 Dec. 1889): 55-6.

29. Fidelis, "The New Ideal of Womanhood," 661.

30. Fidelis, "Higher Education for Women,” 149; see also "Woman's Work,” Rose Belford's Canadian Monthly and National Review 1 (Sept. 1878), 295-311.

31. J.S. Mill, in On Liberty and other writings, ed. Stefan Collini (Cambridge: Cambridge University Press, 1989; The Subjection of Women first published in 1869), Chapter 3. The view that their education was in part responsible for women's apparent inferiority already had a long history dating at least from Mary Astell in the seventeenth century. See Ruth 
launching one of her frequent darts at the academic standards of ladies' finishing schools, a critique which had found expression in her first novel Katie Johnstone's Cross, where a certain academy for young ladies was ridiculed for priding itself in "verbal accuracy of repetition and neat sewing." 32 Such critiques of schools for ladies were fairly common although not wholly warranted by the evidence. ${ }^{33}$

Machar's analysis was probably based less on the experiences of women students in Canada than on a widely held belief that education available to daughters of the upper and middle classes was not training them for anything useful and, worse, was actively producing mental inferiority. ${ }^{34}$ Although Machar advocated that girls be given a systematic training in the same academic subjects as boys, she wavered on the question of identical co-education. One factor that she found in its favour at all levels of schooling was its presumed tendency to delay rather than encourage "Cupid's insidious advances" by removing any "foolish illusions" about the other sex. ${ }^{35}$ Yet she took issue with the largely identical coeducation that had evolved in Canadian common schools, going so far as to say that "there are much greater dangers and drawbacks attending co-education in the earlier than in the later years of study," and that a single curriculum for boys and girls at the common school level was a "coercive measure."36 In keeping with the domestic destiny forwhich women were to be primed, Machar

Roach Pierson, "Two Marys and a Virginia: Historical Moments in the Development of a Feminist Perspective on Education," in Women and Education: A Canadian Perspective, ed. Jane Gaskell and Arlene McLaren (Calgary: Detselig, 1987): 203-22.

32. Katie Johnstone's Cross; A Canadian Tale (Toronto: J. Campbell, 1870), 5.

33. See Marjorie Theobald, “'Mere Accomplishments?’ Melbourne’s Early Ladies' Schools Reconsidered,” History of Education Review 13 (1984): 15-28. For in-depth studies that reveal the high standards of some schools for young women in Ontario, see Johanna Selles-Roney, “'Manners and Morals'? or 'Men in Petticoats'? Education at Alma College, 1871-1898,” and Elizabeth Smyth, “"A Noble Proof of Excellence': The Culture and Curriculum of a Nineteenth-Century Ontario Convent Academy,” in Gender and Education in Ontario: An Historical Reader, ed. Ruby Heap and Alison Prentice (Toronto: Canadian Scholars Press, 1991). See also Johanna M. Selles, Methodists and Women's Education in Ontario, 1836-1925 (Montreal and Kingston: McGill-Queen's University Press, 1996).

34. See George Monro Grant's 1879 address to the Montreal Ladies' Educational Association, "Education and Co-education," Rose-Belford's Canadian Monthly 3 (November 1879): 509-18.

35. Fidelis, Higher Education for Women,” 148.

36. Fidelis, "A Few Words on University Co-education," Rose-Belford's Canadian Monthly and National Review 8 (Mar. 1882): 313-19; quotation, 318. 
maintained that household management should occupy a central place in the curriculum of any reputable system of female education. Lessons in domestic economy for girls, furthermore, would resolve many of the concerns raised with respect to female education:

There is no reason why a woman of cultivated mind should be unfit for the right discharge of housewifely duties; no necessary connexion between a liberal education, literary and scientific tastes, and an untidy ménage—badly cooked and ordered meals, and neglected children...may there not be found, in a judicious commingling of intellectual and practical education, the golden mean we want, and the best corrective to the tendency of schools to overwork the mind?...domestic duties, in moderation, are a useful relief from mental strain; just as some mechanical or other active work is to masculine students. ${ }^{37}$

Almost twenty years later, Adelaide Hoodless's first address to the National Council of Women similarly proposed "industrial training" (domestic science) for girls in the public schools. ${ }^{38}$

The extolling of woman as helpmeet and mother was a favourite refrain in progressive and conservative quarters. The main difference was that the progressives believed education would equip women to do the job better, and the conservatives feared that partaking of the fruit of the forbidden tree might lead women to relinquish their wifely and maternal roles altogether.

English historian Jane Lewis has pointed out that for some social activists, the family was seen as mediating between the individual and the state: "It was not therefore perceived as a private and separate sphere, but rather as the fundamental unit of the polis and as such the agent of social progress as well as the object of social reform." 39 Brian Fraser's analysis of how male social gospellers within the Presbyterian Church of Canada attempted to create a "Christian collective conscience" reveals a similar conception of the "Christian home."

37. Fidelis, "Higher Education for Women," 156.

38. NCWC Report (1894): 114-30.

39. Jane Lewis, Women and Social Action in Victorian and Edwardian England (Hants, England: Edward Elgar, 1991), 7.

40. Brian Fraser, The Social Uplifters: Presbyterian Progressives and the Social Gospel in Canada, 1875-1915 (Waterloo: Wilfred Laurier University Press, 1988), 119. 
the mother's work of Christian nurture suggests an understanding of the domestic world as foundational to the public world rather than isolated from and subordinate to it. ${ }^{41}$ Although this conception of the domestic sphere did nothing to change its economic, political, and legal subordination, at least some of the veneration of home and hearth pouring from pulpits and the popular press was not merely the expression of conservatism, but of a profoundly religious hope. With this added nuance, Machar's views of marriage and motherhood may be considered less subservient to the status quo. If she did not contest the hegemony of middle-class domestic ideology, she saw a significant difference between the old and new ideal of womanhood, although the chief end of marriage and motherhood may have remained the same. The "clinging-vine type" of woman, "absolutely dependent on man for any life worth living," had been displaced by an ideal of woman as the "divine guide, purifier, inspirer of the man." ${ }^{2}$ A thorough education would not be thrown away on the woman who subsequently married, but would equip her to raise "the intellectual and moral average" of the next generation. ${ }^{43}$

Machar followed the clear distinction generally made between a liberal education and a specialized one. She shared the common view that a liberal education aimed for the highest intellectual and moral development of the individual, whereas a specialized one prepared the person for a career. Thus she could argue forcefully for a liberal education for women in order to make the domestic machinery run smoothly and bolster the character of the nation, without "trespassing unnecessarily...upon the disputed question of woman's work." 44 Despite her disclaimer, Machar took up the disputed question of woman's work in detail.

Machar's discussion about women in the professions and in paid work went in two directions: first, that women be given the

41. For further evidence of this belief, see Marguerite Van Die, An Evangelical Mind: Nathanael Burwash and the Methodist Tradition in Canada, 1839-1918 (Montreal and Kingston: McGill-Queen's University Press, 1989).

42. Fidelis, “The New Ideal of Womanhood,” 659 and 676. In the latter instance, Machar was quoting from an unknown source by Charles Kingsley (1819-1875), professor of modern history at Cambridge, founder of the Christian Socialist movement, and prolific writer on social/political questions. She also relied heavily on an article in a London magazine by Mrs. Fawcett, “The Old and New Ideals of Women’s Education,” Good Words (1878): 853-67.

43. Fidelis, "The New Ideal of Womanhood," 661; see also "The Higher Education of Women," 56.

44. Fidelis, "Higher Education for Women," 153. 
opportunity to provide for themselves, in the absence of a suitable marriage; and second, that they be free to develop their God-given talents to the fullest extent possible without regard to sex. Interlacing these two themes was what amounted to a diatribe against the aimlessness and idleness of girls in the middle and upper classes. She had nothing but scorn for women "who live only to spend the earnings of others" and who lead "aimless and useless lives" in comparison to their working sisters. ${ }^{45}$ Frequently she repeated that it was the vacuity of women's lives rather than overstudy that was the cause of ill health. ${ }^{46}$ She was highly critical of the life of "fashionable dissipation" encouraged among daughters of "easy circumstances," and she traced their listlessness to their superficial education, which equipped them for little more than "inane pursuits" and "intellectual atrophy." 47

How many daughters of the Canadian middle classes actually spent leisured lives reading potboilers, and paying vapid social calls like the fictional Lottie in Machar's serialized novel Lost and Won, is difficult to assess. ${ }^{48}$ This sort of woman was likely a character of the imagination more than of real life, especially in a sparsely populated country where even wealthy families had difficulty obtaining and retaining domestic help. The necessity of women's household labour to produce goods for family consumption was an enduring feature of the Canadian economy in the nineteenth century. ${ }^{49}$ Chances were that few households could permit their daughters to languish in ennui. Yet, as a member of a congregation that included some of Canada's most prominent families, Machar had plenty of opportunity to observe affluence, and her critique of the wealthy may have indicated her disappointment in what she saw. Certainly the hypocrisy of church-

45. Fidelis, "Woman's Work,” 310.

46. Fidelis, "Higher Education for Women," 147 and 151-2; “The New Ideal of Womanhood,” 663-5; “A Few Words,” 317; and “The Enlarged Conception of Woman’s Sphere: Professor Fitch's Views on the Subject,” The Week 7 (10 Oct. 1890): 713-4. 47. Fidelis, "Higher Education for Women," 151 and 154.

48. Lost and Won: A Canadian Romance was serialized in the Canadian Monthly and National Review 7 (1875).

49. Marjorie Griffen Cohen, Women's Work: Markets, and Economic Development in Nineteenth-Century Ontario (Toronto: University of Toronto Press, 1988), 119; Patricia Branca, "Image and Reality: The Myth of the Idle Victorian Woman," in Clio's Consciousness Raised: New Perspectives on the History of Women, ed. Mary Hartman and Lois W. Banner (New York: Harper \& Row, 1974): 179-89. 
going Christians refusing to perform even the simplest acts of charity was a theme that received attention in her novels. ${ }^{50}$

Whether she was responding to myth or reality, she was nevertheless persistent and persuasive in urging women to put aside their crochet and crewel work and take up useful employment. While reviewing with unreserved optimism the gains that women had made in entering universities and the professions in the British Empire and the United States, Machar surveyed a wide range of occupations where women who wished to remove themselves from an idle dependence on the labour of others could maintain themselves with dignity. ${ }^{51}$ Moreover, Machar urged "adequate remuneration" for their work, saying, "The principle of paying women less than men for the same work is one so essentially unjust that only a thoughtless and blind conventionality could have so long perpetuated it.” On this subject she did not mince words, insisting that women would prefer fair pay to chivalry any day:

...the moment that the principle of self-interest comes into play, the average man is more ready to grind down, to overreach, to under-pay, to cheat outright a woman than a man, just because he thinks he can do it with impunity. It is small wonder if women feel that the compensation of a thin veneer of social courtesy for the ability to earn an honest independence, is very like offering a stone for bread! ${ }^{52}$

Nonetheless, almost twenty years later, when the pros and cons of protective labour legislation for female factory workers were argued in the annual meetings of the National Council of Women, no party to the debate, including Machar, insisted that the issue of equal pay for equal work be incorporated in the legislative demands

50. See her denunciation of Mrs. West in Marjorie's Canadian Winter, A Story of Northern Lights (Boston: D. Lothrop Company, 1892), 107, and Reverend Cecil Chillingworth in Roland Graeme, Knight, A Novel of Our Time (London: Digby, Long and Co., 1895).

51. Fidelis, "The New Ideal of Womanhood," 670-6. Machar relied on a British source for her information on women's entry into universities. For further discussion of what Machar considered suitable occupations for women, see "Higher Education for Women," 153-5; “Woman's Work,” 306-11.

52. Fidelis, "The New Ideal of Womanhood," 675. She is alluding to Matthew 7:9—“Who of you if their children ask for bread would give them a stone?” 
formulated by the Council. That female factory workers were paid far less than men was well known. ${ }^{53}$

Machar's review of suitable occupations for women included, among others, medicine, law, mission work, and journalism. Machar reminded her readers that the prejudice against women practising medicine was a relatively recent innovation; in fact, women had a long history in the healing arts, a history which Machar sketched from ancient Greece to the eighteenth century. Drawing heavily on the English writers Charles Kingsley and Sophia Jex-Blake, she devoted considerable attention to promoting the restoration of medical practice to women on the grounds that it was "a work for which woman is peculiarly fitted and peculiarly needed." She also noted the "bitter and unreasonable opposition" that attended the "so-called innovation" of women entering medicine. ${ }^{54}$ As Machar was drawing on British and American sources, it is difficult to judge exactly to what opposition she was referring or what, in fact, she made of the situation as it was unfolding in Canada. The "short-lived 'experiment' in medical coeducation”,55 at Queen’s in 1880 provoked a raging controversy or, as Machar in a classic understatement put it, "certain inconveniences" ${ }^{56}$ that threatened the continuance of the school, a situation eventually resolved by a return to separate education with the founding of Women's Medical Colleges in Toronto and Kingston.

Machar was doubtful "that any but very exceptional women [would] find their way into the courts of law." Nonetheless, although she maintained that the profession of law was less suited to women than medicine, and "almost the last, indeed, for which a woman might seem adapted," she saw no reason why it should be closed to those exceptional women whose talents took them in that direction. ${ }^{57}$ One wonders if Machar's opinions on women's suitability for a career in law were inspired by her barrister brother.

Machar suggested mission work as deserving women's special consideration. Like those of women in other Protestant

53. Backhouse, Petticoats and Prejudice, 283.

54. Fidelis, "Woman's Work," 310.

55. On the controversy, see Paula J.S. LaPierre, "The First Generation of Women University Students in Central Canada” (Ph.D thesis, University of Toronto, 1993), 78-82; quotation, 78.

56. Fidelis, "Queen's University and What It Has Done for Canada in the Past," The Canada Educational Monthly 11 (Mar. 1889): 91-8.

57. Fidelis, "The New Ideal of Womanhood," 672. 
denominations during the last quarter of the nineteenth century, Presbyterian women's religious energies were typically directed to Sunday schools, and home and foreign missions. ${ }^{58}$ In fact the urgent call from foreign mission fields for medical missionaries further demonstrated the justice of training female physicians to attend female patients in countries where cultural norms prevented women from being treated by men. ${ }^{59}$ Yet Machar was silent on the question of women in the ordained ministry. A church court that shuddered at the possibility of a woman's name appearing in the official minutes was hardly likely to welcome one in the pulpit. ${ }^{60}$ Indeed, it was late in the twentieth century before women in the Presbyterian Church achieved ecclesiastical suffrage and a rather cool reception into the ordained ministry.

Machar also outlined the possibility of a career in journalism, although not encouragingly:

Tyros or dilettantes "need not apply," and should well count the cost of a thorough preparation for literary work before they commit themselves to what is at best an ill-paid profession as a means of subsistence. Unless they are prepared to submit to years of apprenticeship, with little or no remuneration, and to persevere in an uphill work in spite of repeated disappointments that sadly clip the wings of young enthusiasm, they had better content themselves with less ambitious aims. ${ }^{61}$

Her cautionary tone might be attributed to her own difficulties in her chosen career, especially in the light of A. Ethelwyn Wetherald's later revelation that Margaret Machar discouraged her daughters literary aspirations "from a belief that a literary vocation was not likely to promote a woman's happiness, and also from a

58. Some of Machar's own contribution to mission work is detailed in The Presbyterian Record 1 (July 1876): 190, and 12 (Sept. 1885): 247; and Canada Presbyterian12 (16 Apr. 1884): 244. On the "siren call" of foreign missions, see Ruth Compton Brouwer, New Women for God: Canadian Presbyterian Women and India Missions, 1876-1914 (Toronto: University of Toronto Press, 1990).

59. Fidelis, “Woman’s Work,” 308. See also “The New Ideal of Womanhood,” 672. On female medical missionaries, see Veronica Strong-Boag, "Canada's Women Doctors: Feminism Constrained,” in A Not Unreasonable Claim: Women and Reform in Canada, 1880s-1920s, ed. Linda Kealey (Toronto: Women’s Press, 1979), 119-23; and Brouwer, New Women for God, 112-19.

60. The Presbyterian Record 1, 2 (Jan. 1876-Dec. 1877): 190.

61. Fidelis, "The New Ideal of Womanhood," 673. 
distaste of anything like notoriety.” Wetherald's explanation that the young Machar's writings were often "orphaned in print" because "she feared her words would be little heeded, if it were known that they owed their being to a mere girl," indicate an acute awareness of discrimination on the basis of sex and age. ${ }^{62}$ Machar was a pioneer in a field neither hospitable to women nor lucrative. Although her estimate of her own literary career is not known, the difficulties of friends such as Louisa Murray and S. Frances Harrison (Seranus) bear out the contention that eking out a living from writing was difficult. ${ }^{63}$

Throughout her discussions, Machar maintained the assumption that university study and professional training would be the sanctuary of only a few women with a rare gift or talent:

What the female students of Ontario are asking is...simply that those exceptional young women who have the taste, the aptitude, the means, and the perseverance, for taking a university course should have the privilege of doing so. ${ }^{64}$

Machar did not argue for nor expect a radical change in gender or class relations upon women's entry into higher education. Indeed, although she took the advance of women's rights as evidence that "the world moves," she assured readers that "invisible chains, nevertheless, hold it firmly in its safe and venerable orbit." 65 Recent scholarship on early women students confirms that no radical change occurred, inside the universities at least. ${ }^{66}$ Still, the mere

62. A. Ethelwyn Wetherald, "Some Canadian Literary Women-II-Fidelis," The Week 5 (5 Apr. 1888): 300-1. See also Gerson, “Three Writers of Victorian Canada,” 204; and Brouwer, "Moral Nationalism in Victorian Canada," 93.

63. See Fidelis, “A Loss to Canadian Literature,” The Week 11 (5 Oct. 1894): 1063-4; Susie Frances Harrison to Louisa Murray, 14 Nov. 1889 and 18 May 1890, York University Archives, Louisa Murray Papers, Box 1, File 10. As acting editor of The Week, Harrison pressured Murray to become a subscriber. She practically begged Murray to buy her books.

64. Fidelis, “A Few Words,” 319.

65. Machar, “The Enlarged Conception of Woman’s Sphere,” 713-4.

66. LaPierre, “The First Generation,” 277-8; Selles, Methodists and Women's Education, Chapter 9; Lynne Marks and Chad Gaffield, "Women at Queen’s University, 1895-1905: A 'Little Sphere’ All Their Own?” Ontario History 78, 4 (December 1986): 330-49; Chad Gaffield, Lynne Marks, and Susan Laskin, "Student Populations and Graduate Careers: Queen's University, 1895-1900,” in Youth, University and Canadian Society: Essays in the Social History of Higher Education, ed. Paul Axelrod and John G. Reid (Kingston and Montreal: McGill-Queen's University Press, 1989), 3-25; Nicole Neatby, 
presence of women in universities was a radical change that eventually wrought irreversible social and political consequences. Their movement into new areas of study and professional work remains a focus of significant research. ${ }^{67}$

Patricia Smith Butcher found in her review of late nineteenthand early twentieth-century American women's rights periodicals that diverse aims were advanced as the purpose of female education, in accordance with varied perceptions of the intended adult role of educated women:

Mothers of the Republic, knowledgeable helpmates, competent citizens, financially independent workers, and trained professionals were the myriad of roles promoted, sometimes simultaneously, within the pages of the women’s rights press." 68

If "Mothers of the Empire" was substituted for "Mothers of the Republic," then Machar could be credited with promoting all of these seemingly paradoxical goals for female education within one article, and repeating them in several others. Her essays offer rich commentary on Victorian beliefs about the place of women in general and female education in particular. Potential conflict between the development of full personhood and the demands of domesticity was suppressed to a degree, but never entirely, by her sanction of wifehood and motherhood as the highest of Christian duties. Yet a consistent theme throughout her work was that women should elaborate their "differing and preeminent gifts" and "develop as God would have them to do."

\footnotetext{
"Preparing for the Working World: Women at Queen's during the 1920s," Historical Studies in Education 1, 1 (Spring 1989): 53-72.

67. See, for example, Elizabeth Smyth, Sandra Acker, Paula Bourne, and Alison Prentice, eds., Challenging Professions: Historical and Contemporary Perspectives on Women's Professional Work (Toronto: University of Toronto Press, 1999).

68. Patricia Smith Butcher, Education for Equality: Women's Rights Periodicals and Women's Higher Education, 1849-1920 (New York: Greenwood Press, 1989), 16. 69. Machar, "Higher Education of Women," 56; see also "Women’s Work,” 311; "The New Ideal of Womanhood," 671-2.
} 
the concept of individual right and used it to advantage in her advocacy of women's higher education and engagement in purposeful work. 